\title{
Diversitas Ikan Karang pada Berbagai Variasi Substrat Karang Mati di Perairan Pulau Liukangloe, Kabupaten Bulukumba
}

\author{
Chair Rani*, Abdul Haris, dan Ahmad Faizal \\ Departemen IImu Kelautan, Fakultas IImu Kelautan dan Perikanan, Universitas Hasanudin \\ Jl. Perintis Kemerdekaan Km.10 Tamalanrea, Makassar 90245 Indonesia \\ Email: erickch_rani@yahoo.com
}

\begin{abstract}
Reef Fish Diversity In Dead Coral Substrates In Liukangloe Island Waters, Bulukumba District
\end{abstract}

Microhabitat variation was one of the key factors that determine diversity of organism associated in coral reefs. The purposed of this study was to analyze species richness and density of reef fish associated with various dead coral substrates. In addition, it also analyzes spatial distribution of reef fishes. Stationary visual census technique was applied to record data of fish speceis number and density on 4 forms of dead coral substrate (massive, branching, tabulate, rubbles, and natural/living corals as a control). The observation area was $2 \times 2 \mathrm{~m}$ and 5 replications were carried out for each substrate. The analysis of variance was to used to compare the number of species and density between substrates and correspondence analysis was used to analyse spatial distribution. Equivalent proportions were found for major, target, and indicator fish, on branching, tabulate and live coral substrates. Dead coral substrates were dominated by target and indicator fish, whereas rubbles were dominated by major and target fish groups. Individual composition was dominated by indicator fish, except for coral rubble which was dominated by target fish. The substrate in the form of branching corals have a higher species richness and fish density compared to rubble, but not significantly different from the tabulate corals and natural corals. Indicator fish (family Chaetodontidae) was spatially distributed mostly on live corals, rubbles were characterized by high Acanthurus pyropherus, Arothron mappa, Halichoeres hotulanus, Abudefduf vagiensis, Caesio xanthonota, and Dascylus auranus, and dead corals were characterized by species of major fish.

Keywords: diversity; reef fish; dead coral substrates; Liukangloe Island

\begin{abstract}
Abstrak
Variasi mikrohabitat di daerah terumbu karang menjadi salahsatu faktor kunci yang menentukan keragaman biota yang berasoiasi dengan terumbu karang. Penelitian ini bertujuan untuk menganalisis kekayaan jenis dan kepadatan ikan karang pada berbagai bentuk substrat karang mati. Selain itu, juga menganalisis sebaran spasial ikan karang. Teknik stationary visual censusdiaplikasikan untuk mendata ikan pada 4 bentuk substrat karang mati (masif, branching, tabulate, pecahan karang mati, dan karang alami/hidup sebagai kontrol). Luas area pengamatan sebesar $2 \times 2 \mathrm{~m}^{2}$ dan dilakukan 5 kali pengulangan untuk setiap substrat.. Perbandingan jumlah jenis dan kepadatan ikan antara substrat dilakukan dengan analisis ragam dan sebaran spasial dengan analisis koresponden. Ditemukan proporsi yang setara untuk ikan major, indikator, dan target pada substrat branching, tabulate dan karang hidup. Substrat karang mati, didominasi oleh ikan target dan ikan indikator. Sedangkan pada substrat berupa pecahan karang mati didominasi oleh kelompok ikan major dan target. Komposisi individu didominasi oleh ikan indikator, kecuali pada substrat pecahan karang, didominasi oleh ikan target. Pada substrat dengan bentuk branching memiliki kekayaan spesies dan kepadatan ikan yang lebih tinggi dibandingkan dengan pecahan karang, namun tidak berbeda nyata dengan substrat karang tabulate dan karang alami.Sebaran spasial ikan indikator (famili Chaetodontidae) banyak ditemukan di substrat karang hidup, sedangkan pada substrat pecahan karang dicirikan oleh tingginya kepadatan ikan Acanthurus pyropherus, Arothron mappa, Halichoeres hotulanus,
\end{abstract}


Abudefduf vagiensis, Caesio xanthonota, dan Dascylus auranus. Ikan major merupakan penciri pada substrat karang mati.

Kata Kunci: keragaman; ikan terumbu; substrat karang mati; Pulau Liukangloe

\section{PENDAHULUAN}

Variasi mikrohabitat di daerah terumbu karang menjadi salah satu faktor kunci yang menentukan keragaman biota yang berasoiasi dengan terumbu karang, termasuk salah satunya ikan karang (Robert \& Ormond, 1987; Rani et al., 2019). Variasi habitat terumbu karang, dalam hal ini variasi mikrohabitat tidak hanya terdiri dari habitat karang saja, tetapi juga ada habitat berpasir, berbagai celah (gua), habitat beralga dan sponge, bahkan sering ditemukan area terumbu yang juga ditumbuhi lamun.

Telah banyak penelitian yang dilakukan untuk melihat keterkaitan habitat di terumbu karang dengan keragaman ikan. Hasilnya memperlihatkan beragamnya faktor yang berperan dalam menentukan keragaman ikan karang. Dalam kebanyakan studi, kompleksitas fisik/substrat terumbu karang berkorelasi positif dengan keragaman ikan, tetapi tidak dengan kelimpahannya (Roberts \& Ormond 1987). Secara biologis sifat substrat, yaitu kekayaan spesies karang dan/atau karang hidup, tidak memiliki pengaruh terhadap keanekaragaman dan kelimpahan ikan (Mc Manus et al., 1981), namun penelitian lain, karakteristik ikan berkorelasi positif dengan karang hidup (Muniaha et al., 2016). Degradasi terumbu karang, baik oleh peristiwa alami (seperti badai, banjir, atau karena peristiwa el Nino) maupun oleh pengaruh antropogenik (misalnya, penangkapan yang merusak, eutrofikasi, dan sedimentasi) memberi kontribusi yang nyata terhadap perubahan struktur biofisik yang mengarah pada penurunan kompleksitas ruang dan habitat di terumbu karang. Fenomena ini dengan sendirinya akan memberi dampak terhadap biota yang berasosiasi, dalam hal ini perubahan struktur komunitas berbagai biota sebagai respons langsung maupun tak langsung terhadap perubahan tersebut. Gangguan yang terjadi pada terumbu karang akan menyebabkan penurunan kelimpahan ikan karang. Menurut Wilson, et al. (2006), dalam jangka waktu yang lebih lama (tahunan) dapat menyebabkan kelimpahan dan keanekaragaman ikan yang lebih rendah.

Kejadian coral bleaching di bulan Mei 2016 di terumbu karang Pulau Liukangloe telah menyebabkan kematian karang dan mengubah struktur dasar terumbu karang, seperti yang dilaporkan oleh Nirwan et al. (2017), fenomena bleaching di terumbu karang Pulau Liukangloe, menyebabkan sekitar 13,12\% tutupan karang di kedalaman $10 \mathrm{~m}$ mengalami bleaching dan sekitar $6-7 \%$ di kedalaman $3 \mathrm{~m}$. Ikan karang yang hidupnya terkait dengan terumbu karang, maka kerusakan atau penurunan kondisi terumbu karang dengan sendirinya berpengaruh terhadap keragaman dan kelimpahan ikan karang. Berdasarkan atas kondisi tersebut maka penelitian ini dilakukan dengan tujuan untuk menganalisis biodiversitas ikan karang (kekayaan jenis dan kelimpahan ikan karang) berdasarkan perbedaan substrat dasar terumbu karang, dalam hal ini variasi bentuk pertumbuhan karang yang mati dan menentukan ikan-ikan penciri di setiap variasi substrat tersebut berdasarkan sebaran spasialnya.

\section{MATERI DAN METODE}

Penelitian ini dilaksanakan di daerah terumbu karang perairan Pulau Liukangloe. Terumbu karang di perairan ini telah dilaporkan mengalami fenomena bleaching dalam skop yang luas di bulan Maret pada tahun 2016. Pulau Liukangloe berada di daerah Tanjung Bira dan menjadi daerah tujuan wisata pantai dan wisata penyelaman di bagian selatan Sulawesi Selatan (Gambar 1).

Pendataan ikan karang dilakukan pada 5 titik untuk masing-masing bentuk substrat karang mati (masif, branching, tabulate, pecahan karang, dan karang 
hidup (sebagai kontrol). Pemilihan area didasarkan pada ketersediaan substrat karang mati yang telah ditentukan dan berada pada kedalaman 3-5m. Berdasarkan penelitian menunjukkan bahwa beberapa lokasi di kedalaman 3-5 m banyak mengalami kematian akibat peristiwa bleaching terutama di Stasiun I, II, dan III (Nirwan et al., 2017). Dari 3 stasiun tersebut, pada Stasiun I dan II masing-masing terdapat 3 area sebagai ulangan dan setiap area tersedia masing-masing substrat karang mati yang dijadikan objek penelitian (termasuk karang alami sebagai kontrol). Sedangkan pada Stasiun 3 terdapat 3 titik dan setiap titik terdapat masing-masing 3 area yang juga sebagai ulangan.

Penelitian ini mengamati keragaman dan kepadatan ikan karang yang berasosiasi dengan 4 bentuk substrat karang mati (bentuk branching, meja/tabulate, masif, dan karang hancur) dan sebagai kontrol juga dilakukan pengamatan di karang hidup/alami. Setiap bentuk substrat (perlakuan) dilakukan pengulangan sebanyak 5 kali (pada 5 titik) dalam bentuk stasiun pengamatan, sehingga didapatkan
15 area pengamatan. Setiap stasiun, diamati 1 titik untuk setiap bentuk substrat dengan luasan area pengamatan $2 \times 2 \mathrm{~m}^{2}$. Jarak antara titik terpisah sekitar 25-50 $\mathrm{m}$ dan diasumsikan tidak terjadi interaksi antara unit sampling (Labrosse et al., 2002).

Pada setiap bentuk substrat dilakukan pengamatan jenis dan kepadatan ikan karang dengan menggunakan teknik Stationary Visual Census, yaitu ikan-ikan karang yang ada pada area $(2 \mathrm{~m} \times 2 \mathrm{~m}$ : 4 : $\mathrm{m}^{2}$ ) dicatat jenis dan jumlah individunya dengan cara berdiam diri pada pusat area pengamatan. Identifikasi ikan-ikan karang dilakukan menurut petunjuk Allen (2000) dan Kuiter dan Tonozuka (2001). Jenis ikan yang didata dikelompokkan dalam 3 kelompok utama, yaitu: a) Ikan target: ikan ekonomis penting dan biasa ditangkap untuk konsumsi; b) Ikan indikator: jenis ikan karang yang khas mendiami terumbu karang dan menjadi indikator kesuburan ekosistem terumbu karang. Ikan indikator ini diwakili oleh famili Chaetodontidae; dan c) Ikan major: merupakan jenis ikan berukuran kecil, umumnya 5-25 cm dengan karakteristik warna.

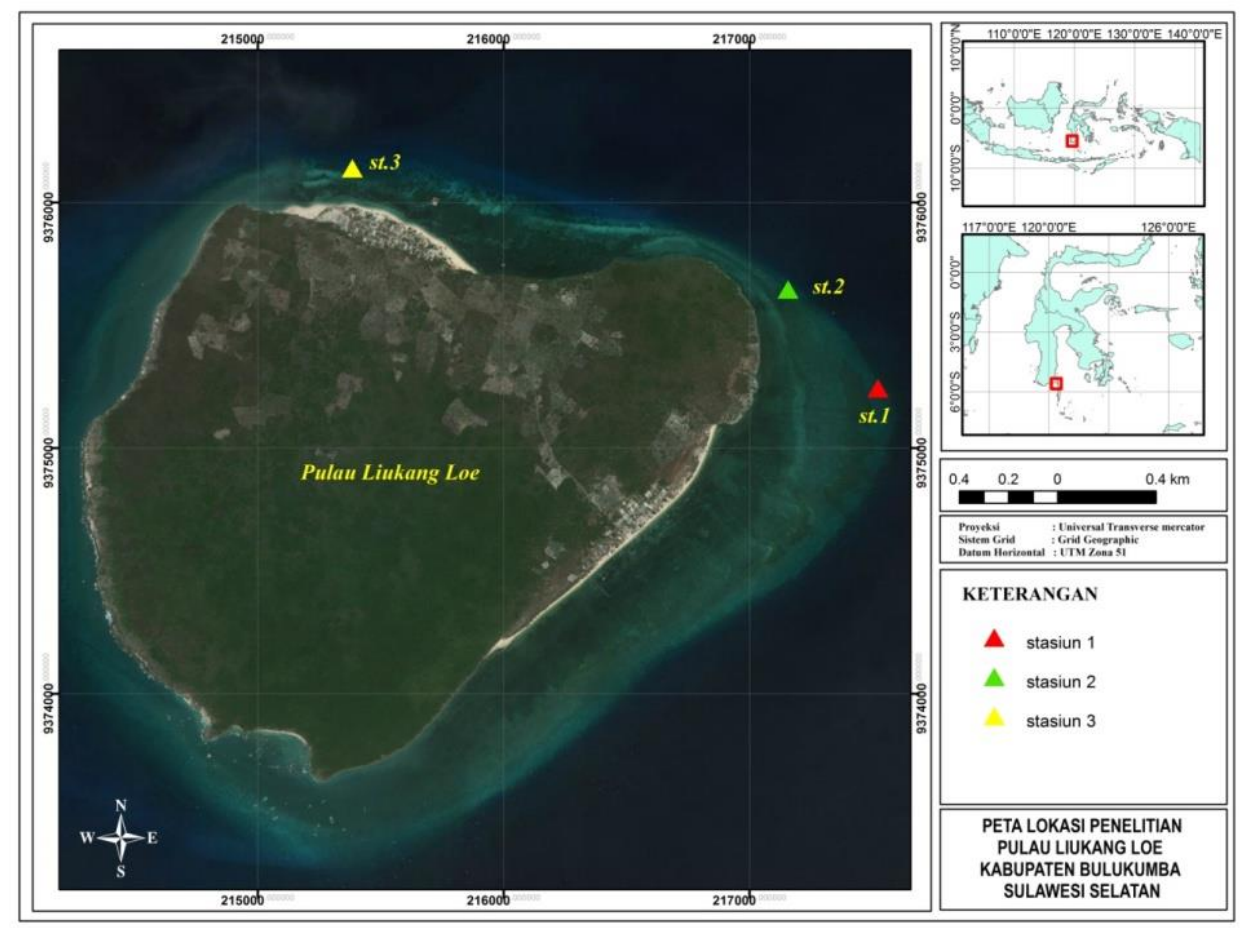

Gambar 1. Lokasi pelaksanaan penelitian di Pulau Liukang Loe, yang terletak di pesisir Pantai Selatan Kabupaten Bulukumba 
Adapun kelimpahan ikan karang dinyatakan dalam satuan jumlah ekor per satuan luasan dengan formula (Labrosse et al., 2002). Komposisi jenis dan individu ikan dikelompokkan menurut substrat karang mati dan dianalisis perbedaannya secara deskriptif dengan bantuan grafik. Jumlah jenis dan kepadatan ikan karang antara substrat dianalisis perbedaannya dengan analisis ragam (one way anova) yang hasilnya disajikan dalam bentuk grafik. Proses penghitungan dilakukan dengan bantuan perangkat lunak SPSS 12.0.

Distribusi spasial ikan karang berdasarkan substratnya digunakan analisis multivariate dengan teknik Correspondence Analysis (COA) dengan bantuan perangkat lunak Minitab 14.0 yang hasilnya disajikan dalam bentuk grafik bidang. Tujuan dari analisis ini, yaitu mendapatkan karakter ikan penciri pada masing-masing substrat. Sebagai tambahan, dikonfirmasi dengan analisis gerombol untuk melihat pola-pola pengelompokan dan kemiripan struktur komunitas ikan karang yang hasilnya disajikan dalam bentuk dendrogram. Proses penghitungannya dilakukan dengan bantuan perangkat lunak Minitab 14.0.

\section{HASIL DAN PEMBAHASAN}

Selama penelitian ditemukan 41 jenis ikan karang. Komposisi dari setiap substrat karang mati pada karang mati-branching karang mati-tabulate dan karang hidup/alami bersifat proporsional antara ikan major, indikator, dan target. Ikan major berjumlah 5-9 jenis, ikan indikator 5-8 jenis, dan ikan target 4-8 jenis (Gambar 2). Sedangkan pada karang mati-masif komposisi ikan indikator sama dengan ikan target, yaitu 8 jenis dan ikan major hanya 5 jenis. Untuk substrat pecahan karang mati, komposisi didominasi oleh ikan major (7 jenis), namun ikan indikatornya hanya 1 jenis.

Dari sisi jumlah individu yang terpantau (449 ekor), komposisi jumlah individu ikan karang didominasi oleh kelompok ikan indikator, kecuali di substrat pecahan karang mati didominasi oleh ikan target. Ikan major hanya mendominasi di daerah substrat karang mati-branching bersama kelompok ikan indikator (Gambar 3).

Banyak kajian telah dilakukan pada ikan-ikan terumbu karang dan menegaskan bahwa ikan major selalu mendominasi dalam hal jumlah jenis dan individu (misalnya Hukom \& Syahailatua, 2010; Rani et al., 2011; 2019; Setiawan et al., 2016). Namun pada investigasi dalam skop yang lebih kecil, seperti dalam kajian ini, difokuskan pada substrat karang mati dalam berbagai bentuk, ternyata perbandingan ketiga kelompok ikan karang tergolong proporsional, bahkan pada substrat karang mati-masif, proporsi ikan major lebih rendah. Proporsi ikan major hanya tinggi pada substrat pecahan karang mati. Terlihat bahwa pada struktur substrat yang kompleks (banyaknya celah) memberikan ruang yang lebih banyak untuk kehidupan ikan karang. Menurut Lindahl et al. (2001), habitat karang mati yang struktur kompleksitasnya tetap bertahan, dapat terus mendukung komunitas ikan karang yang berlimpah dan beragam. Hubungan antara substrat dan variabel ikan (kekayaan jenis dan keragaman ikan) berkorelasi dengan banyak variabel karang seperti kompleksitas arsitektur (atau cakupan karang bercabang), keanekaragaman, kekayaan spesies, kelimpahan, ukuran koloni, tutupan karang hidup, karang masif dan karang mengerak (Chabanet et al., 1997).

Tingginya jumlah jenis ikan karang pada substrat karang mati-branching sangat terkait dengan kompleksitas yang diberikan melalui celah-celah yang tersedia di antara cabangcabang karang. Dalam kebanyakan studi, kompleksitas fisik substrat terumbu adalah positif berkorelasi dengan keragaman komunitas ikan, tetapi tidak dengan kelimpahannya (Roberts dan Ormond 1987; Muniaha et al., 2016; Ghiffar et al., 2017; Rani et al., 2019). Banyak faktor yang menentukan keragaman dan kelimpahan ikan karang, selain tutupan karang hidup atau karang mati. Beberapa faktor tersebut seperti keberadaan atau kedekatan dengan ekosistem sekitarnya seperti kehadiran padang lamun dan mangrove (Rani et al., 2011), tingkat rugositas (Muniaha et al., 2016), dan keberagaman mikrohabitat atau kompleksitas habitat (Rani et al., 2011). 


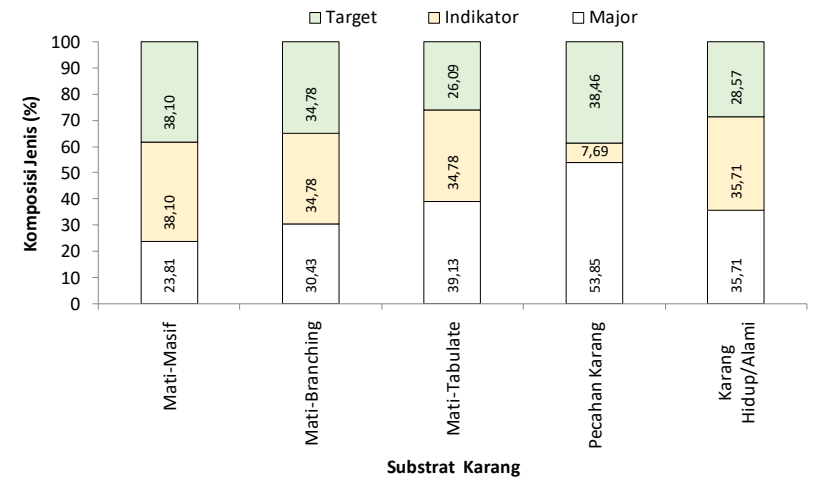

(a)

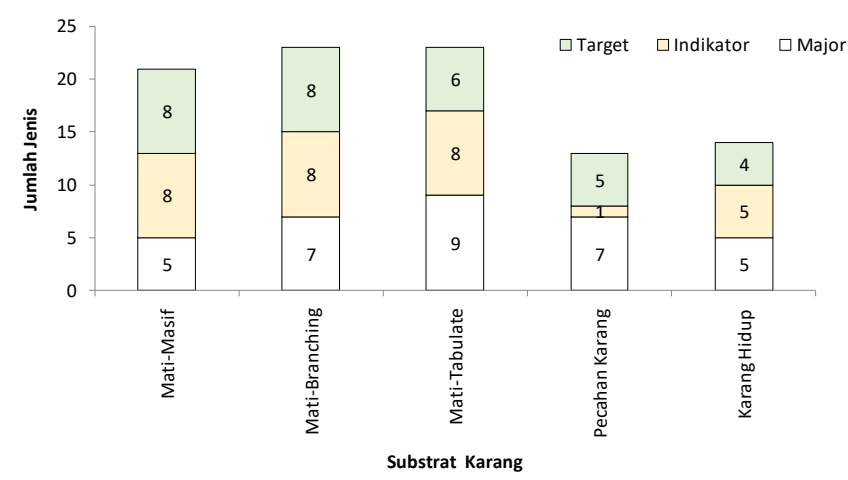

(b)

Gambar 2. Komposisi jenis (a) dan jumlah jenis (b) ikan karang pada berbagai variasi substrat dasar berdasarkan penggolongan ikan karang

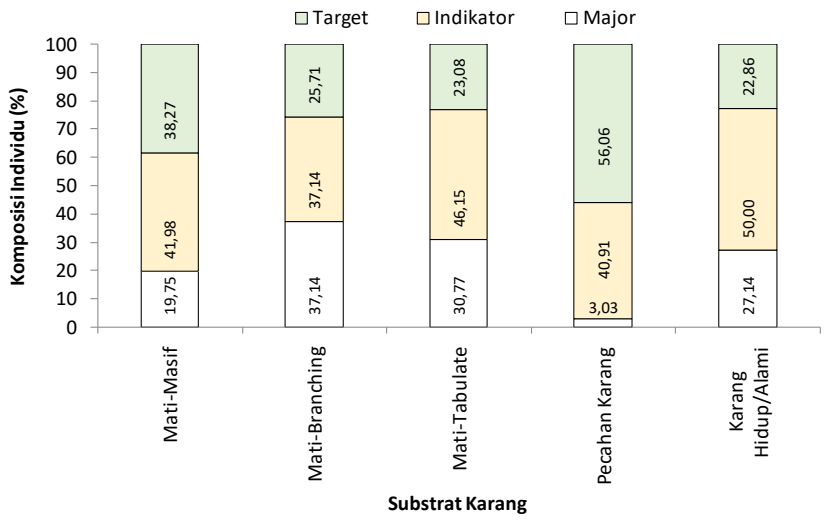

(a)

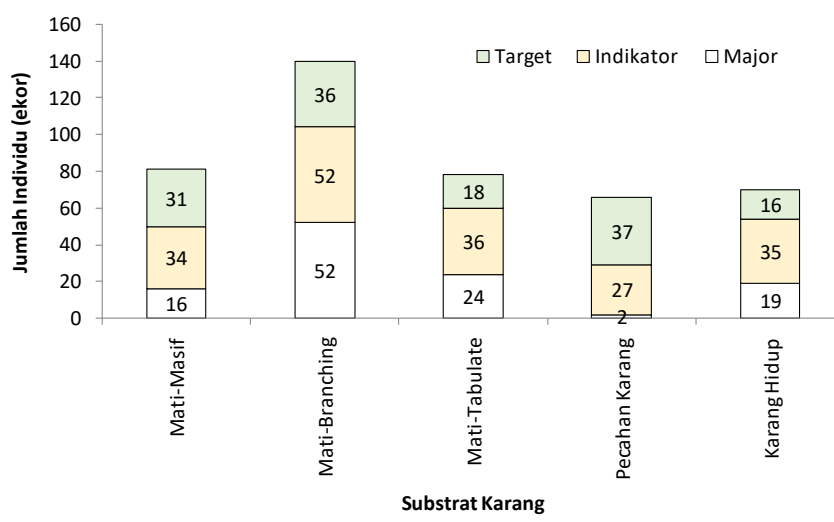

(b)

Gambar 3. Komposisi individu (kiri) dan jumlah individu (kanan) ikan karang yang ditemukan pada berbagai variasi substrat dasar menurut penggolongan ikan karang

Berdasarkan penggolongan ikan karang, hasil analisis terhadap jumlah jenis menunjukkan bahwa hanya ikan indikator saja (famili Chaetodontidae) yang memperlihatkan variasi yang nyata $(p<0,05)$ antara substrat karang mati. Sedangkan Ikan major dan target tidak memperlihatkan perbedaan yang nyata $(p>0,05)$, termasuk dengan karang alami atau kontrol (Gambar 4). Jumlah jenis ikan indikator tertinggi ditemukan pada substrat karang matibranching (3,2 jenis), kemudian disusul oleh substrat karang mati-tabulate (2,4 jenis), dan karang hidup $(2,33$ jenis), ketiganya tidak berbeda nyata, namun berbeda nyata dengan substrat pecahan karang mati $(0,20$ jenis: jumlah jenis terendah).

Ikan Chaetodontidae adalah salah satu kelompok penting dari komunitas ikan di ekosistem terumbu karang dan telah digunakan sebagai bioindikator kesehatan terumbu karang, terutama yang bersifat obligate coral feeder/predator seperti Chaetodon kleinii (Reesa, 1981; Wibowo et al.,2013). Keragaman dan kelimpahan mereka sangat terkait dengan keanekaragaman dan kondisi terumbu karang. Umumnya, spesies dari kelompok ini kehidupannya sangat tergantung pada karang sebagai tempat berlindung permanen, berkembang biak, dan mencari makan. Sebagian besar kelompok ikan ini menjadikan polip karang sebagai makanannya secara mutlak (obligate coralfeeder), namun ada juga yang bersifat fakultatif (facultative coral feeder), zooplankton feeder, dan non-coralline vertebrate feeder (Sano, 1987). Faktor keragaman relung makanan dari ikan 
Chaetodontidae menjadi penyebab ditemukannya kelompok ikan ini di substrat karang mati, bahkan menyamai kekayaan jenis pada karang hidup dalam penelitian ini. Jumlah jenisnya lebih kaya dibandingkan dengan substrat karang mati-masif dan pecahan karang mati dengan struktur fisik yang lebih sederhana. Selain karena faktor makanan, kehadiran kelompok ikan ini pada substrat karang mati kembali ditentukan kompleksitas substrat (banyak celah yang terbentuk di antara cabang pada branching dan tabulate). Bahkan pada jenis C. trifascialis sangat kuat berasosiasi dengan karang cabang tabulate di banyak lokasi (Reesa, 1981). Kepadatan ikan karang antara substrat karang mati berdasarkan penggolongan ikan karang, menunjukan kelompok ikan indikator yang memperlihatkan variasi yang nyata $(p<0,05)$, sedangkan kelompok ikan major dan ikan target tidak menunjukkan variasi yang nyata ( $>>0,05)$ (Gambar 5).
Dalam skop ruang yang kecil, komposisi dan jumlah individu kelompok ikan major hampir proporsional dengan ikan indikator. Hal yang menarik terlihat pada ikan target, ditemukan melimpah pada substrat pecahan karang. Faktor keterbukaan area di pecahan karang menjadi alasan banyaknya ikan target yang mengunjungi area tersebut dan diduga dimanfaatkan sebagai area feeding ground. Kelimpahan ikan target yang tinggi di substrat pecahan karang mati, yaitu pada jenis Caesio xanthonota dan Acanthurus pyropherus. Keberadaan alga (DCA) yang tumbuh pada pecahan karang menjadi alasan tingginya kelimpahan jenis ikan-ikan tersebut. Menurut Carpenter (1988), Caesio merupakan pemakan zooplankton, sedangkan Acanthurus merupakan pemakan alga yang tumbuh di karang dan batuan, meskipun beberapa spesies juga memakan detritus (Fishelson \& Delarea, 2014). Kehadiran kedua jenis ikan tersebut menunjukkan ketersediaan makanan yang

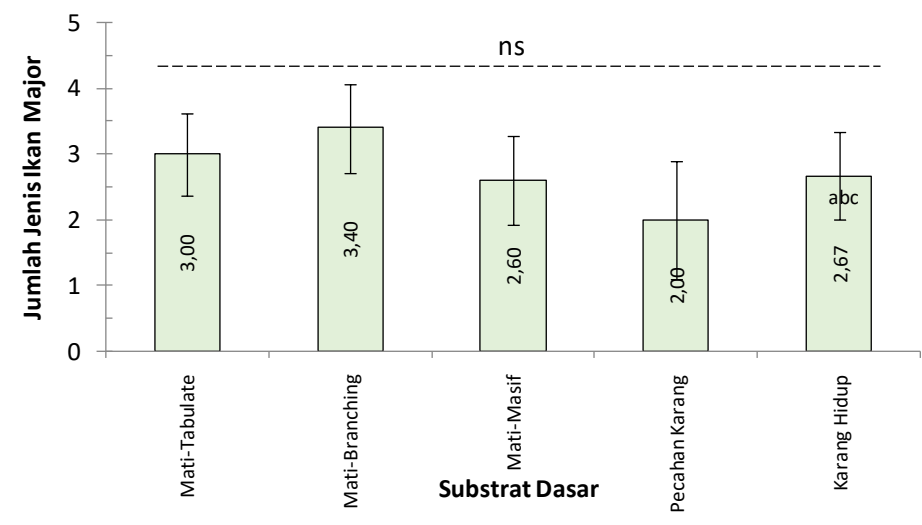

(a)

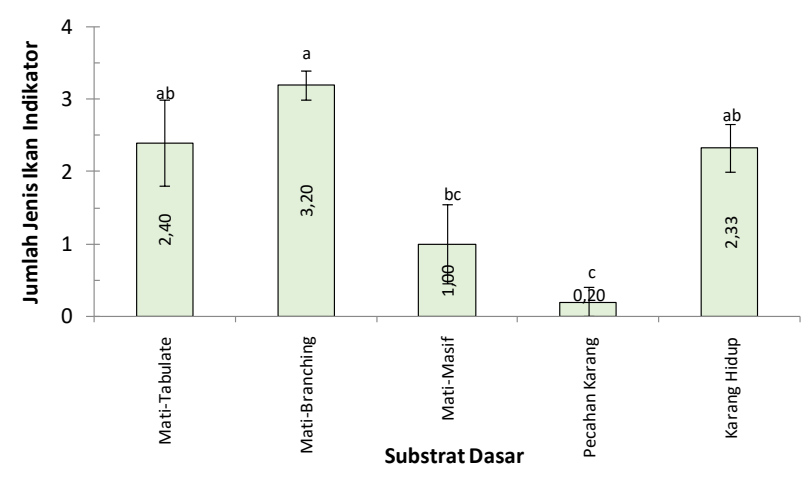

(b)

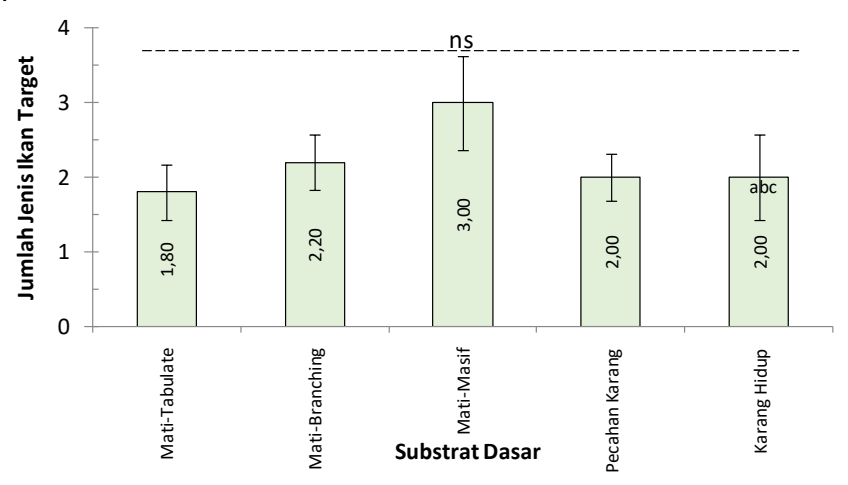

(c)

Gambar 4. Rata-rata jumlah jenis ikan karang menurut kelompok ikan major (a), indikator (b), dan target (c) pada berbagai variasi substrat karang mati 


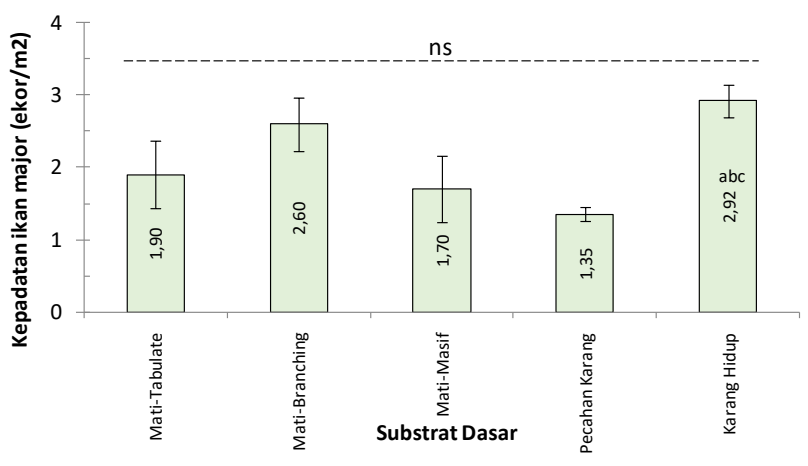

(a)

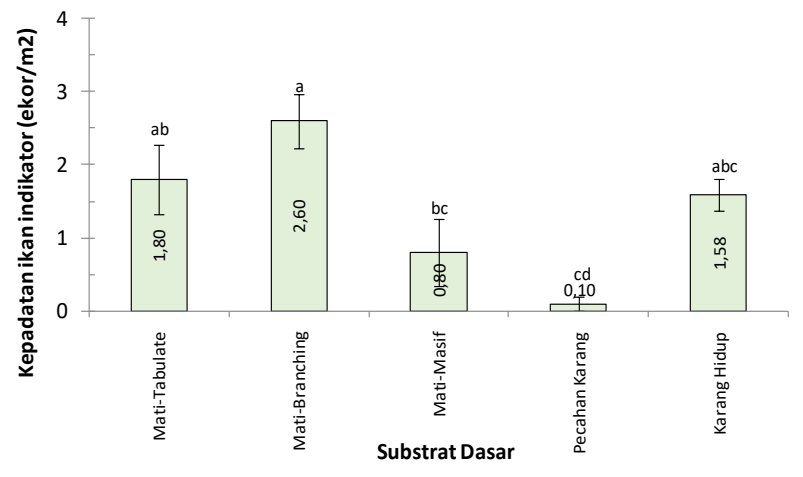

(b)

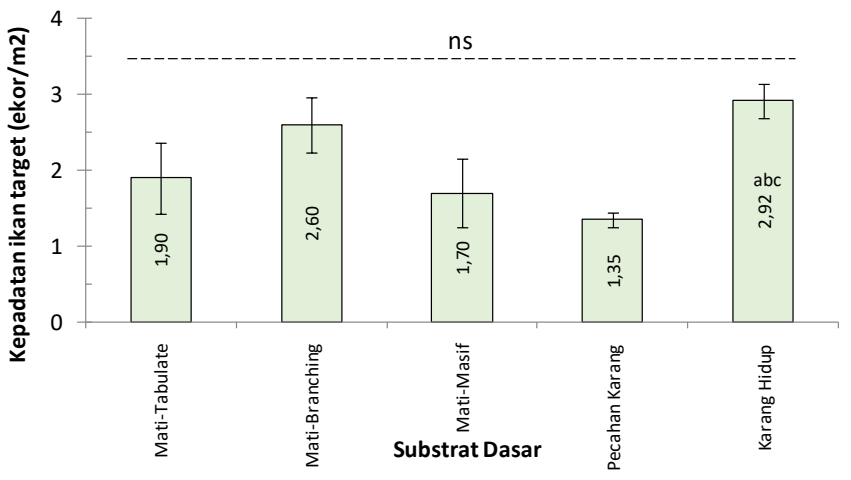

(c)

Gambar 5. Rata-rata kepadatan ikan karang menurut kelompok ikan major (a), indikator (b), dan target (c) pada berbagai variasi substrat karang mati

berlimpah, yaitu alga filamen pada pecahan karang mati di dasar dan kelimpahan zooplankton di kolom air.

Secara umum, ditemukan adanya variasi yang nyata terhadap jumlah jenis dan kepadatan ikan karang pada berbagai substrat karang mati $(p<0,05)$. Rata-rata jumlah jenis ikan karang yang tertinggi ditemukan pada substrat karang matibranching, yaitu 8,8 jenis dan nyata berbeda $(p<0,05)$ dengan jumlah jenis ikan pada substrat pecahan karang mati (4,2 jenis) (Gambar 6). Tidak ditemukan perbedaan jumlah kekayaan jenis ikan antara substrat karang mati-tabulate, karang mati-masif, substrat pecahan karang mati, dan karang hidup. Sedangkan untuk kepadatan ikan karang, tertinggi di substrat karang matibranching dan berbeda nyata dengan substrat karang mati-masif dan pecahan karang $(p<0,05)$, namun tidak berbeda nyata dengan substrat karang mati-tabulate dan karang hidup $(p>0,05)$ (Gambar 6)
Kompleksitas atau struktur ruang yang disediakan oleh karang bercabang berpengaruh kepada kekayaan dan kelimpahan ikan karang dalam penelitian ini. Tampak bahwa lingkungan yang sangat kompleks memungkinkan habitat untuk digunakan bersama oleh banyak spesies (Barbault, 1992). Pengrusakan habitat, yang menyebabkan penurunan besar tutupan karang bercabang (Naim, 1993), dapat mengurangi jumlah spesies ikan (Chabanet et al., 1995).

Hasil analisis koresponden, memperlihatkan ada 3 kelompok distribusi spasial ikan karang berdasarkan substrat karang mati yang diamati. Penggunaan dua sumbu utama (Sumbul dan Sumbu 2) hanya mampu menjelaskan sekitar $70,75 \%$ distribusi spasial ikan (Gambar 7). Ketiga kelompok tersebut, yaitu 1) substrat yang berupa pecahan karang yang dicirikan oleh banyaknya ikan Caesio xanthonota, Dascyllus auranus, Acanthurus pyropherus, 
Arothron mappa, Halichoeres hatulanus, dan Abudefduf vagiensis, kelompok ikan ini sebagian besar merupakan ikan target; 2) substrat karang hidup yang dicirikan oleh sebagian besar ikan-ikan indikator dalam jumlah yang tinggi, seperti Chaetodon octofasciatus, Chaetodon triangulum, Chaetodon collare, Chromis viridis, Chromis actipectoralis, dan Heniochus pleurotania; dan 3) substrat karang mati-tabulate, karang mati-masif, dan karang mati branching memiliki struktur komunitas ikan yang mirip

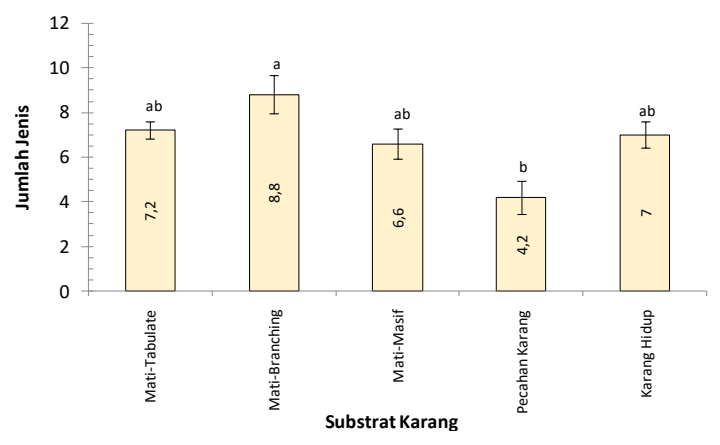

(a) dan sebagian besar dari kelompok ikan major, kemudian ikan target.

Pada substrat berupa pecahan karang mati, sebagian besar ikannya dicirikan oleh kehadiran ikan target yang melimpah. Keterbukaan substrat pecahan karang (struktur ruang yang sederhana) menyebabkan banyak kelompok ikan, terutama ikan target yang memanfaatkannya sebagai daerah feeding ground. Mereka ke sana selain memakan

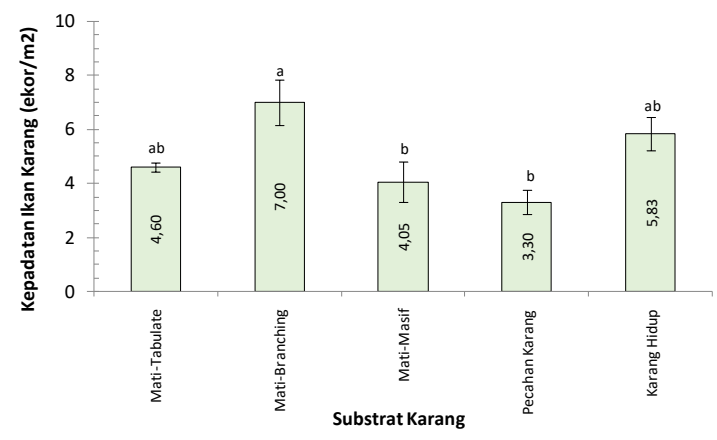

(b)

Gambar 6. Jumlah jenis (a) dan kepadatan (b) ikan karang yang ditemukan pada berbagai variasi substrat dasar. Huruf yang berbeda di atas grafik menunjukkan perbedaan yang nyata pada a:5\% berdasarkan analisis ragam

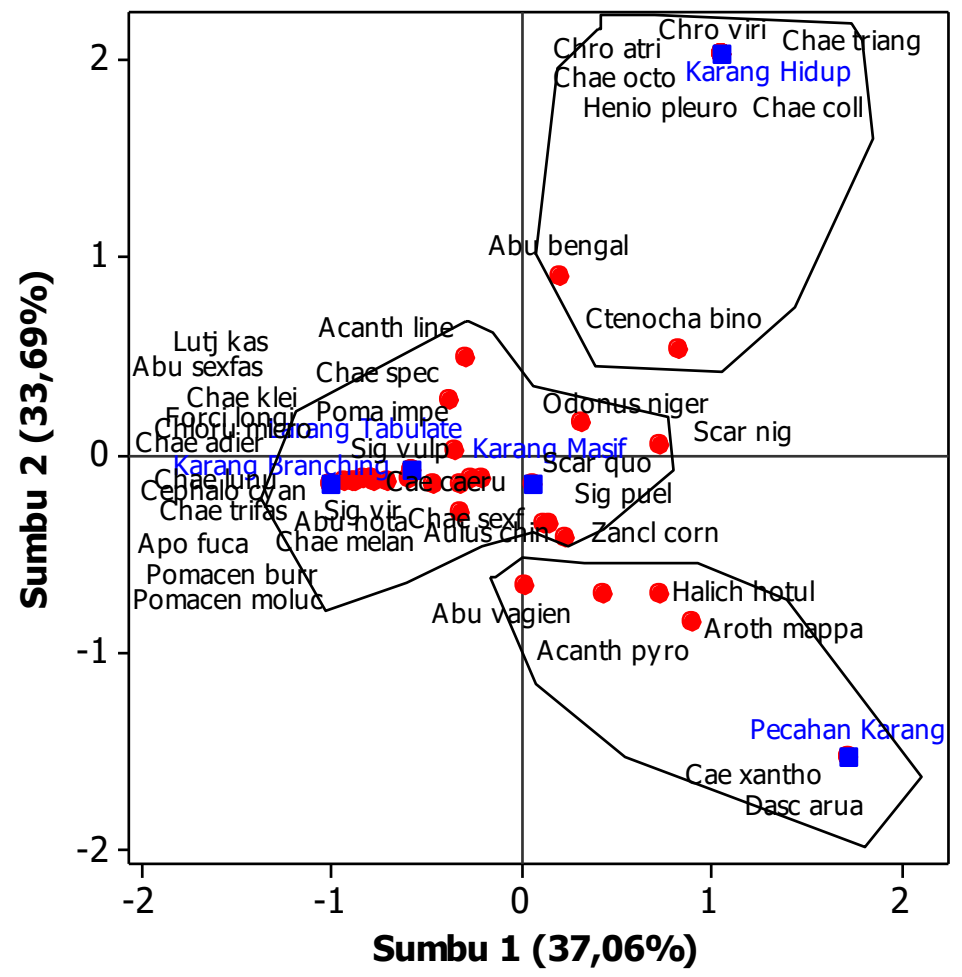

Gambar 7. Distribusi spasial sebaran ikan karang pada berbagai variasi substrat dasar berdasarkan hasil analisis koresponden. 
alga yang tumbuh di permukaan seperti pada kelompok ikan kakak tua (Scaridae) dan ikan butana (Acanthuridae), beberapa kelompok ikan pemakan hewan bentik sering juga ditemukan, seperti ikan kerapu (Serranidae) atau kakap (Lutjanidae). Pada substrat karang hidup, dicirikan oleh kelimpahan ikan indikator dari famili Chaetodontidae. Beberapa jenis ikan Chaetodontidae bersifat obligat coral feeder sehingga sangat bergantung pada karang hidup (polip karang) sebagai makanannya. Menurut Harmelin-Vivien \& Bouchon-Navaro (1981), karang hidup lebih banyak digunakan sebagai sumber makanan oleh Chaetodontidae, di mana sebagian besar spesies adalah koralivora. Beberapa penulis (Chabanet et al., 1995; Bouchon-Navaro et al., 2005) telah menemukan korelasi positif antara kelimpahan Chaetodontidae dan persentase karang hidup.

Substrat karang mati berbentuk masif, branching, dan tabulate memiliki penciri dari kebanyakan ikan major, meskipun ada beberapa ikan target seperti kelompok Siganidae juga ditemukan, serta beberapa jenis dari kelompok ikan indikator (Chaetodontidae). Kemiripan struktur komunitas ikan karang memang paling tinggi ditemukan antara substrat karang mati-tabulate dan masif, yaitu sebesar $72,18 \%$. Struktur ikan karang pada kedua bentuk substrat tersebut hanya memiliki kemiripan sekitar $64 \%$ dengan struktur ikan karang pada karang alami, sedangkan karang branching dengan ketiga substrat yang disebut sebelumnya hanya mirip sekitar $56 \%$.

\section{KESIMPULAN}

Pada substrat karang mati, jumlah jenis didominasi oleh ikan target dan indikator, sedangkan pada substrat pecahan karang didominasi oleh ikan major dan target. Kelimpahan ikan karang pada berbagai substrat didominasi oleh ikan indikator, kecuali pada substrat pecahan karang yang didominasi oleh ikan target. Substrat karang mati-branching memiliki jumlah jenis dan kepadatan ikan karang yang lebih tinggi. Kelompok ikan indikator (family Chaetodontidae) menjadi penciri pada substrat karang hidup. Sedangkan pada substrat pecahan karang, dicirikan oleh melimpahnya ikan target dan pada substrat karang mati (branching-tabulate, dan masif) lebih dicirikan oleh kehadiran ikan major yang melimpah.

\section{DAFTAR PUSTAKA}

Allen, G.R. 2000. Marine fishes of South East Asia. Kaleidoscope Pront and Prepress Perth.Western Australia. 292p.

Bouchon-Navaroa, Y., Bouchon, C., Louis, M., \&Legendre, P. 2005. Biogeographic patterns of coastal fish assemblages in the West Indies. J. Experiment. Mar. Biol. Ecol., 315(1):31-47. doi: 10.1016/j.jembe. 2004.08.028

Carpenter, K.E. 1988. FAO Species Catalogue. Vol. 8. Fusilier fishes of the world. An annotated and illustrated catalogue of caesionid species known to date. Rome: FAO. FAO Fisheries Synopsis 125(8):iv+75p

Chabanet, P., Dufour, V., \& Galzin, R.1995. Impact of disturbance on reef fish communities in Reunion Island (Indian Ocean). J. Experiment. Mar. Biol. Ecol., 188(5):29-48. doi: 10.1016/0022-0981(94) 00184-F

Chabanet, P., Ralambondrainy, H., Amanieu, M., Faure, G., \& Galzin, R.1997. Relationships between coral reef substrata and fish. Coral Reefs, 16(2): 93102. doi: $10.1007 / \mathrm{s} 003380050063$

Fishelson, L.\& Y. Delarea, Y. 2014. Comparison of the oral cavity architecture in surgeonfishes (Acanthuridae, Teleostei), with emphasis on the taste buds and jaw "retention plates". Environ. Biol. Fishes., 97(2):173-185. doi: 10.1007/s10641-013-01 39-1

Ghiffar, M.A., Irham, A., Harahap, S.A., Kurniawaty, N.\&Astuty, S. 2017. Hubungan kondisi terumbu karang dengan kelimpahan ikan karang target di perairan Pulau Tinabo Besar, Taman Nasional Taka Bonerate, Sulawesi Selatan. Spermonde, 2(3):17-24.

Harmelin-Vivien, M.L. \& Bouchon-Navaro, Y. 1981. Trophic relationship among Chaetodontid fishes in the Gulf of Aqaba (Red Sea). Proceeding $5^{\text {th }}$ International Coral Reef Symposium. 2 : 537-544

Hukom, F.D. \& Syahailatua, A.2010. Pemanfaatan dan Pengembangan Potensi Sumberdaya Ikan Karang di Perairan Pulau Ambon dan Sekitarnya. 
Prosiding Seminar Tentang Oseanologi dan IImu Lingkungan Laut dalam rangka Penghargaan kepada Prof. Dr. Aprilani Soegiarto, M.Sc. APU. Pusat Penelitian dan Pengembangan Oseanologi, Jakarta, 7 Oktober 2010. HIm.:233-243.

Kuiter, R.H. \& Tonozuka, T. 2001. Pictorial Guide to Indonesian Reef Fishes. Part1, 2 and 3. Zoo Netics, Seaford Victoria, Australia.893pp.

Labrosse, P., Kulbicki, M., \& Ferraris. J. 2002. Underwater Visual Fish Census Surveys: Proper use and implememtation. Secretariat of the Pacific Community Noumea, New Caledonia. 54pp.

Lindahl, U., Öhman, M.C., \& C.K. Schelten, C.K.2001. The 1997/1998 Mass Mortality of Corals: Effects on Fish Communities on a Tanzanian Coral Reef. Mar. Poll. Bull., 42(2):127-131

McManus, J.W., Miclat, R.I., \& V.P. Palaganas, V.P. 1981. Coral and fish community structure of Sombrero Island, Batangas, Philippines. Proceeding $4^{\text {th }}$ International Coral Reef Symposium, (2):271-280. Manila:18-22 May 1981.

Muniaha, H., Nur, A.l., \& Rahmadani. 2016. Studi kelimpahan ikan karang berdasarkan kondisi terumbu karang di Desa Tanjung Tiram Kabupaten Konawe Selatan. J.Manaj. Sumber Daya Perairan, 2(1):9-19.

Nirwan, Syahdan, M., \& Salim, D. 2017. Studi Kerusakan Ekosistem Terumbu Karang Di Kawasan Wisata Bahari Pulau Liukang Loe Kabupaten Bulukumba Provinsi Sulawesi Selatan. Mar. Coast. Small Islands J., I(1):1 1-22.

Rani, C., Burhanuddin, A.I., \& Attjo, A.A. 2011. Sebaran dan keragaman ikan karang di Pulau Barranglompo; Kaitannya dengan kondisi dan kompleksitas habitat. In Isnansetyo, A. et al. (eds.). Prosiding Seminar Nasional Tahunan VII, Hasil
Penelitian Perikanan dan Kelautan Tahun 2011 Jilid II: Manajemen Sumberdaya Perikanan. Jurusan Perikanan dan Kelautan, Fakultas Pertanian, Universitas Gadjah Mada, Yogyakarta, Tanggal 16 Juli 2011. KLO1: 1-15.

Rani, C., Haris, A., Yasir, I., \& Faizal, A. 2019. Sebaran dan kelimpahan ikan karang di perairan Pulau Liukangloe, Kabupaten Bulukumba. J. Ilmu Teknol. Kelaut. Trop., 11 (3):527-540. doi :10.29244/jitkt.v11i1.205 57

Reese, E.S., 1981. Predation on corals by fishes of the family Chaetodontidae. Implications for conservation and management of coral reef ecosystems. Bull. Mar. Sci., 31 (3):594-604.

Roberts, C.M. \& Ormond, R.F. 1987. Habitat complexity and coral reef diversity and abundance on Red Sea fringing reefs. Mar. Ecol. Prog. Ser. 41 (1 1):1-8.

Sano, M., Shimizu, M., \&Nose, Y. 1987. Longterm effects of destruction of hermatypic corals by Acanthaster planci infestation on reef fish communities at Iriomote Island, Japan. Mar. Ecol. Prog. Ser., 37(5): 91-199.

Setiawan, F., Tasidjawa, S., Wantah, E., \&. Johanis, H. 2016. Biodiversitas Ikan Karang Di Daerah Perlindungan Laut Kabupaten Minahasa Utara, Sulawesi Utara. J. IImu Teknol. Kelaut. Trop., 8(1):57-71.

Wibowo, K., Adrim, M., \&Makatipu, P.C. 2013. Community structure of Chaetodontidae in the west of Banda sea. Mar. Res. Indo. 38(1):1-8. doi: 10.14203/mri.v38i1.51

Wilson, S.K., Graham, N.A.J., Pratchett, M.S., Jones, G.P., \& Polunin, N.V.C. 2006. Multiple disturbances and the global degradation of coral reefs: are reef fishes at risk or resilient? Global Change Bio., 12(11):2220-2234. doi: 10.11 $11 / j .1365-2486.2006 .01252 . x$ 